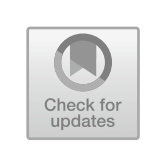

\title{
Reading Comics for Citizenship
}

As noted in the last chapter, different people, due to a variety factors, can experience the same comic in different ways (Duncan, Smith, \& Levitz, 2015). Indeed, as McLaughlin (2012) notes, readers of comic books can find meanings that the creators never even intended. As such, the objective of the assignments in this chapter and the next chapter is to generate conversations about citizenship and history using the comics medium and not to lead students to any predetermined ideas. The assignments in the chapter center on chronology, skills and dispositions, the ten NCSS standards, the social and behavorial sciences, emotional considerations, mythology, and Buddhist political theory. But these are my created assignments and by no means exhaustive. There are so many possibilities regarding comics and citizenship and I have only scratched the surface.

Comic books and graphic novels can also be thought of as "sociocultural artifacts that must be studied as products-both physical and ideological-within the timelines and cultures they evolve from" (Ricca, 2012 , 190). Essentially, all ideas in comics have some sort of meaning "within historical contexts" and this meaning can be examined with evidence (e.g., close readings of the text) (Ricca, 2012, 190). This fact should be accounted for by anyone who seriously studies comics. While it may be beyond the scope of some classes and teachers to have their classes perform a full in-depth historical analysis, the fact that comics are socio-cultural artifacts should at least be made apparent. Further, a short

A. J. Letizia, Graphic Novels as Pedagogy in Social Studies, Palgrave Studies in Global Citizenship Education and Democracy, https://doi.org/10.1007/978-3-030-44252-1_2 
historical analysis of the comics selected for the various exercises can be integrated into any activity in this chapter or the next chapter.

Something I learned very quickly from implementing these frameworks is that many students are not familiar with the comic book format. In fact, my students outright told me this and said they needed more preparation in comic reading. Students will need to be familiar with certain terms and aspects of graphic novels, such as panel, gutter, and dialogue balloon to name a few things. Before assignments I hold quick lectures and discussions on the comics' medium explaining some of these basic terms and gauging my student's understanding. I also started to give my classes a "cheat sheet" with helpful terms. I went through many iterations of this cheat sheet, but I have included my most recent one below. This can serve as a discussion point for class discussion. I encourage teachers to modify this as they see fit.

\section{Comics Cheat Sheet}

Comics: "juxtaposed pictorial images in deliberate sequence intended to convey information" (McCloud, 1994, 9) or Sequential art (Eisner, 2002).

Encapsulation: What portions of a story are depicted and not depicted. These decisions are made by the creators (Duncan et al., 2015; Eisner, 2002).

Sequential Visual Storytelling (SVS): what is shown, not shown, choices of framing, angle and layout, order and sequence of visuals, "emphasis visual elements are given to one another" (Potts, 2013, 14).

Series/Sequence: In a series there is not a strict causality between images. A sequence is more traditional, these are more integrated images (Groensteen, 2013).

Gutter: Space between panels (McCloud, 1994).

Closure: Act of mentally envisioning what happens in the gutter (McCloud, 1994).

Impacts: Cognitive or affective impacts on the reader (Duncan et al., 2015).

Interanimation of meaning: The use of word and text elements and the power of combining them (Duncan et al., 2015).

Braiding: translinear readings, reoccurring motifs (Groensteen, 2007).

Multilinearity: Two or more simultaneous stories taking place on one page (Cabero, 2019). 


\section{The Past}

Chronology is "a clear sense of the order in which events occurred" and it is a crucial concept for students to master when studying history (Chapin, 2015, 219). There is always debate on what or which events to study however (Chapin, 2015). Getz and Clarke (2011) argue that historians do not simply present past events, historians must interpret those occurrences. Further, as Banks and colleagues (1999) note, those interpretations are heavily influenced by culture and the time of writing. Two different people can perceive the same event in different ways and each person's perception of the sequence and events can then further impact how they see the world. I contend that students can utilize the features of the comics medium, particularly its sequential nature and closure, to dive into this question of chronology and past construction. This assignment points to how citizens interpret events of the past in different ways. These differing conceptions may shape the way citizens participate in the republic. They can examine how creators of existing comics think about the construction of the past, and then formulate their own ideas. There is no right answer here, rather, there is your answer and how you chose to justify it.

As noted in the introduction, the notion of closure (McCloud, 1994) has been an important one for comics theory and scholarship. When we perform closure, we populate the gaps of the gutter with our imagination (Hoeness-Krupsaw, 2018). Closure also entails utilizing one's background knowledge (Duncan et al., 2015). McCloud (1994, 70-72) identified six types of panel transitions: moment to moment (where two different moments are shown. This usually does not necessitate much closure), action to action (where one subject is shown performing different actions), subject to subject (panels show different subjects within the same scene. This requires more closure), scene to scene (where different scenes are shown), aspect to aspect (panels show different aspects of a scene, like different components of a bedroom. Furthermore, this transition is not time bound. It can show different components without a lapse in time). Finally, there is a non sequitur transition, which shows seemingly unrelated images.

Students can consider closure when grappling with chronology and past events. Students can examine a historical graphic novel and think about what events are shown and what events they imagine in the gutters. Teachers could also work to integrate Saraceni's (2016) ideas of repetition (where elements are repeated, helping to link panels) and collocation (where elements might have similarities, again, helping to link panels) as 
well and asking how these items may be present and how they impact historical meaning and understanding. The assignment below was inspired in part by Duncan and colleagues $(2015,137)$ experiment, where they asked readers to interpret a comic and gauged the different reactions. This exercise will require teacher discretion. Teachers may want to assign specific excerpts, ideally one page. For historical graphic novels to use in class, teachers can consult Chapter 6.

\section{Closure and History}

Directions: Use the notion of closure to understand how history is written.

1. Find a partner. Decide on three gutters to examine. What events might have taken place in the gutters, what events can you imagine that may have happened in the gutters, and why do you think this is the case? Without consulting each other, think about what occurred in the gutter.

2. Consider how you as an individual constructed the events. What did you use to construct these events, what informed your thought process? How might you translate this process to the construction of a history?

3. Compare answers. What similarities are there? Differences?

4. What might the similarities and differences say about how two individuals view and construct the same historical event?

I utilized this assignment in my social studies methods course as well as in various undergraduate and doctoral history of education courses. There were only five students in my methods course which made for a more intimate setting. I used an excerpt from Maus and from Barefoot Gen. First I assigned Maus and we discussed our interpretations as a class so students could understand the process of closure. Next I assigned a page from Barefoot Gen (a survivor's tale of Hiroshima) and had them go through the questions on the assignment. One group of students had very different interpretations of the excerpt from Barefoot Gen, and the other group had similar ones. I worked with the remaining student, and both she and I brought very different interpretations to the text. Some of the differences for both excerpts were: some students "heard" sounds such as the whistle of the bomb or the eerie silence 
after the gas did its work. Some students did not hear them. One student thought about her own children and what she would have done in the gas chamber. Some students thought of Hollywood movies they had seen which depicted the gas chambers and the nuclear explosions to help them see the image. An older student remembered the palpable and very real fear of nuclear holocaust she experienced in the 1980s, while I remembered my grandfather's description of the shadow imprints of human beings that he saw when he was stationed in Hiroshima in the 1950s. I used this assignment to get my students to think about how different individuals interpret the same historical events. I think closure is well suited to facilitate this discussion. I was also very pleased when a student referenced this activity later on to show how different people process the same event. We bring our own ideas, experiences, and background knowledge to the comics page (Duncan et al., 2015) and this was on full display during our activity and class discussion.

Another variation of this exercise utilizes Cohn's (2018) use of visual narrative grammar (VNG). Cohn $(2018,2)$ asserts: "this 'narrative grammar' gives categorical roles to visual image units, and then organizes those units into hierarchic constituents." Cohn asserts that a basic set of panels are establisher, initial, peak, and release panels. Establishers begin a sequence but are passive, initials start the action, peaks are the action, and release "releases the tension" (Cohn, 2018, 2-3). The meaning produced relies on the combinations, but is also affected by the content as well (Cohn, 2013, 73). Further, more complex types of combinations of panels are called arcs and work to advance complex stories. So, for example, Cohn $(2018,3)$ illustrates an arc with a larger initial and peak, but the larger initial is composed of an initial and peak panel, and the larger peak is composed of an establisher, initial, peak, and release. While Cohn $(2013,2)$ likens comics to a language, he stresses however that "comics are not a language," but created with language (Cohn, 2013).

Students are to take a historical graphic novel or piece of comics journalism and use Cohn's categories to analyze it. Students can consider which depicted events might be establishers, initials, peaks, and releases. Further, students can diagram more complex linkages and story arcs. (Some introduction of Cohn's work and visual grammar, as well as some of Cohn's example would probably be useful here.) 


\section{The Grammar of History}

Directions: This assignment calls for you to argue for a "grammar of history." You will break depictions of historical events down into grammatical parts.

1. Find examples of establishers, initials, peaks, and releases as well as larger arcs.

2. Justify your answers to question one.

3. Pick a specific story arc. Consider your knowledge of history. What other events could you add to this story arc? What would you label these events (establishers, initials, peaks, or releases)?

\section{Skills ANd Dispositions Framework}

Teaching the concept of citizenship is difficult due to the complexity of citizenship outlined in the first chapter. Moreover, I find teaching teachers and how to teach citizenship in hyperreality is even more difficult. One useful method I have found to convey these ideas to my prospective social studies teachers is through the use of skills and dispositions. Cohen, Pickeral, and Levine (2010) and Torney-Purta and Vermeer Lopez (2006) argue that citizens need certain skills and dispositions. Larson $(2017,8)$ asserts that a disposition can be thought of asthe "attitudes or mindsets that students need to learn." Banks and colleagues (1999) similarly argue that citizens need knowledge, skills, values, and to take action. Banks and colleagues (1999) do note however that many times values can conflict (e.g., freedom and equality). Banks and colleagues (1999, 435 ) also note the difference between values and attitudes. They describe values as more general and "not related to any specific things, persons, or groups." Importantly, the questions of what skills and dispositions are needed depend on the type of society that is desired (Cohen et al., 2010). Moreover, Cohen and colleagues (2010) drawing off Westheimer and Kahne's (2004) tension between different types of citizenship, assert that it is difficult to create a totalizing vision of citizenship. Rather, there should be deliberation about what constitutes good citizenship and this should be kept in mind when discussing skills and dispositions (Cohen et al., 2010).

The skills and dispositions should be organic and evolving. Moreover, hyperreality may necessitate new skills and dispositions. A recognition and 
appreciation of hyperreality, may be a new disposition, while navigating it may be a new skill. Further, the fostering of these skills and dispositions are not just the province of the social studies. Different disciplines and fields can help promote different types of skills and dispositions. The use of comics and graphic novels in the social studies, and in a variety of different K-12 and college classes may be able to help with this task. While I do not reference skills and dispositions in every single assignment in this book, I think all of the exercises necessitate certain stills and dispositions, and teachers and professors can highlight, refine and work toward these as they utilize the assignments in this book. Torney-Purta and Vermeer Lopez's $(2006,4)$ notion of "the braid" is important as well: knowledge, skills, and dispositions must be "equal in importance and connected to one another." This equivalence depicted with an interlocking braid of three strands, where each strand represents either knowledge, skills, or dispositions.

I have found the notion of skills and dispositions an effective method to teach the complexity of citizenship in the hyperreal because I can actually show students how to think about citizenship. Students can conceptualize actions and attitudes associated with citizenship and promote these actions and attitudes in their students. I will caution however that I do not think citizenship should ever be made to fit into boxes. Possessing certain skills and dispositions does not automatically make you a great citizen. Citizenship is just so complex. Nevertheless, I think an understanding of skills and dispositions and values are a great start and an effective gateway into teaching citizenship in the hyperreal.

Students can begin to locate these skills and dispositions (and the lack of them) in comics and graphic novels. As argued in the first chapter, comics and graphic novels may make a fecund ground to accomplish this task for a number of reasons. The use of visual- and text-based literacies, as well as the emotional context might be able to help students to further "see" skills and dispositions in action.

Below is the Skills/Dispositions/Citizenship Template. Please note that I have combined all the skills and dispositions/values above into a manageable portion. My skills and dispositions list draws from a number of sources (Banks et al., 1999, 6; Cohen et al., 2010, 80-81; Torney-Purta \& Vermeer Lopez, 2006, 21-23). In addition, I have also included a discussion of Westheimer and Kahne's (2004) tripartite framework of citizenship as well as Parker's (1996) differing notions of democracy. Students are to use the guide and look for evidence of these things in a graphic novel. Here, Meyer and Jimenez's (2017) notion of 
"interrogator" who examines issues of power in a comic is useful, as are the notions of the gutter (Hoeness-Krupsaw, 2018). These guides do not need to be answered in their entirety, they can just be used to spark a discussion. In addition, teachers may want to highlight different skills and dispositions that I have not included. Most likely, a number of prompts and questions will not apply to any given excerpt or whole graphic novel (Table 2.1).

I have used this framework in my social studies methods class. (I have also given it at an academic conference had participants in my session complete it.) This was actually the first piece of this book that I tested in my classes. I was very nervous at first because I did not know how my adult students would react. Yet I was pleasantly surprised. I gave them excerpts from The Killing Joke, the Walking Dead, Maus, and a comic dealing the Slavery and the Civil War. The students used the framework to analyze the excerpts. The framework generated some great conversation about how the features of the comics medium interacted with citizenship ideas, as well as how these were portrayed visually. Importantly, we had also been discussing skills and dispositions of citizenship, as well as the Westheimer and Kahne's (2004) tripartite framework of citizenship since the first weeks of class, so students had some familiarity with the material.

Some further questions and exercises that students can be asked in regards to the notion of the gutter, and really to the process of synecdoche and working from limited information are listed below. Please note that the second question below was inspired by Hutchinson's (2009) assignments. Of course these are only guides. The answers will change depending on what type of material a professor or teacher selects. In addition, teachers or professors may discuss the material beforehand and establish some context or link it to something they are learning. (For instance, the last question may require some discussion and example of multilinearity.) I have given some hypothetical situations below the questions to illustrate some possible questions and answers.

Consider the page. What other information would you like to know? (e.g., character motivations, historical facts, etc.) Why would you like to know this information? Would it help you come to any conclusions?

Think about what certain characters may think about their own actions, how the character may describe or rationalize these actions to others, or how an outside observer may understand the actions being shown. Create a thought bubble for a single character, a conversation between two or more characters, or narrate a panel or panels. 


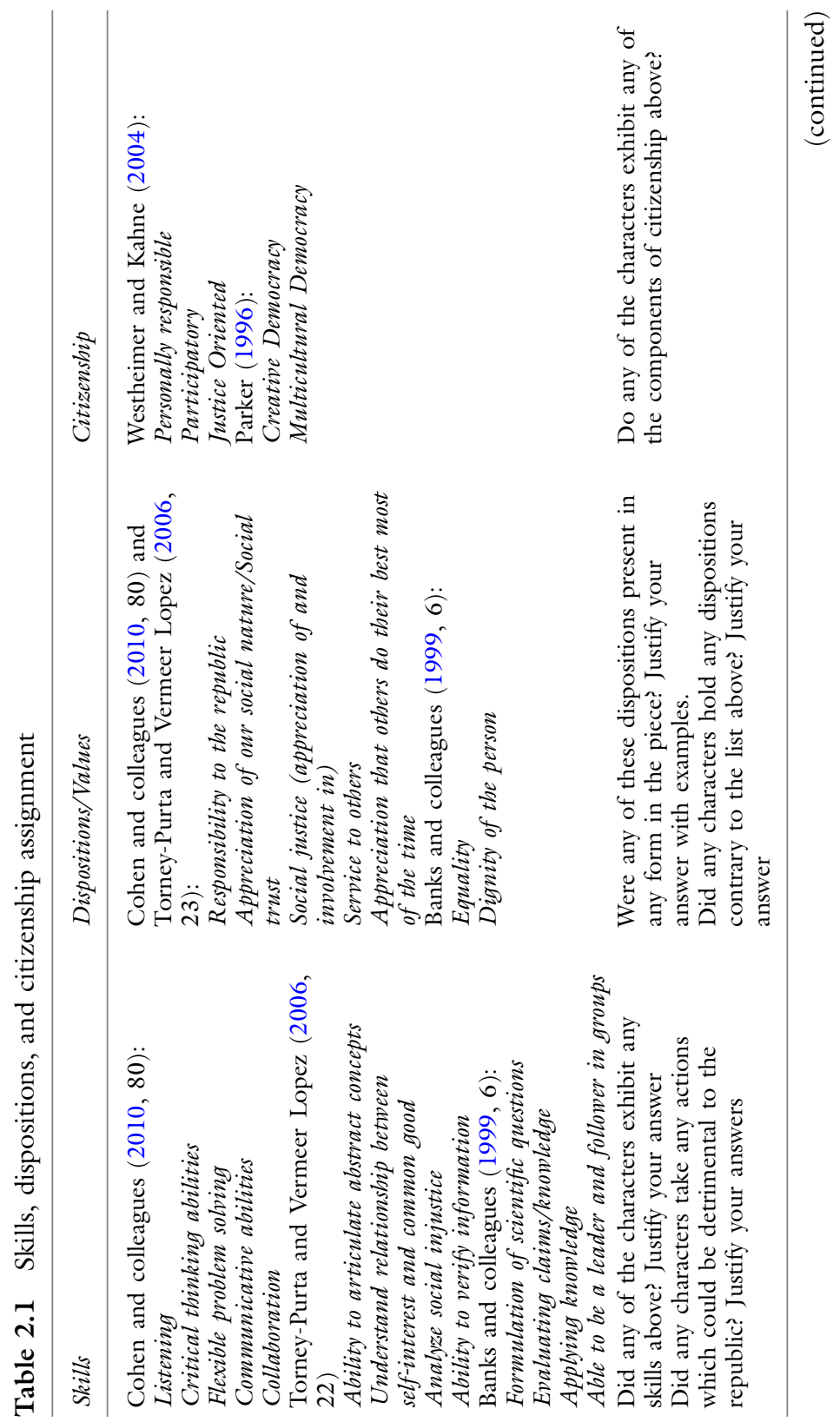




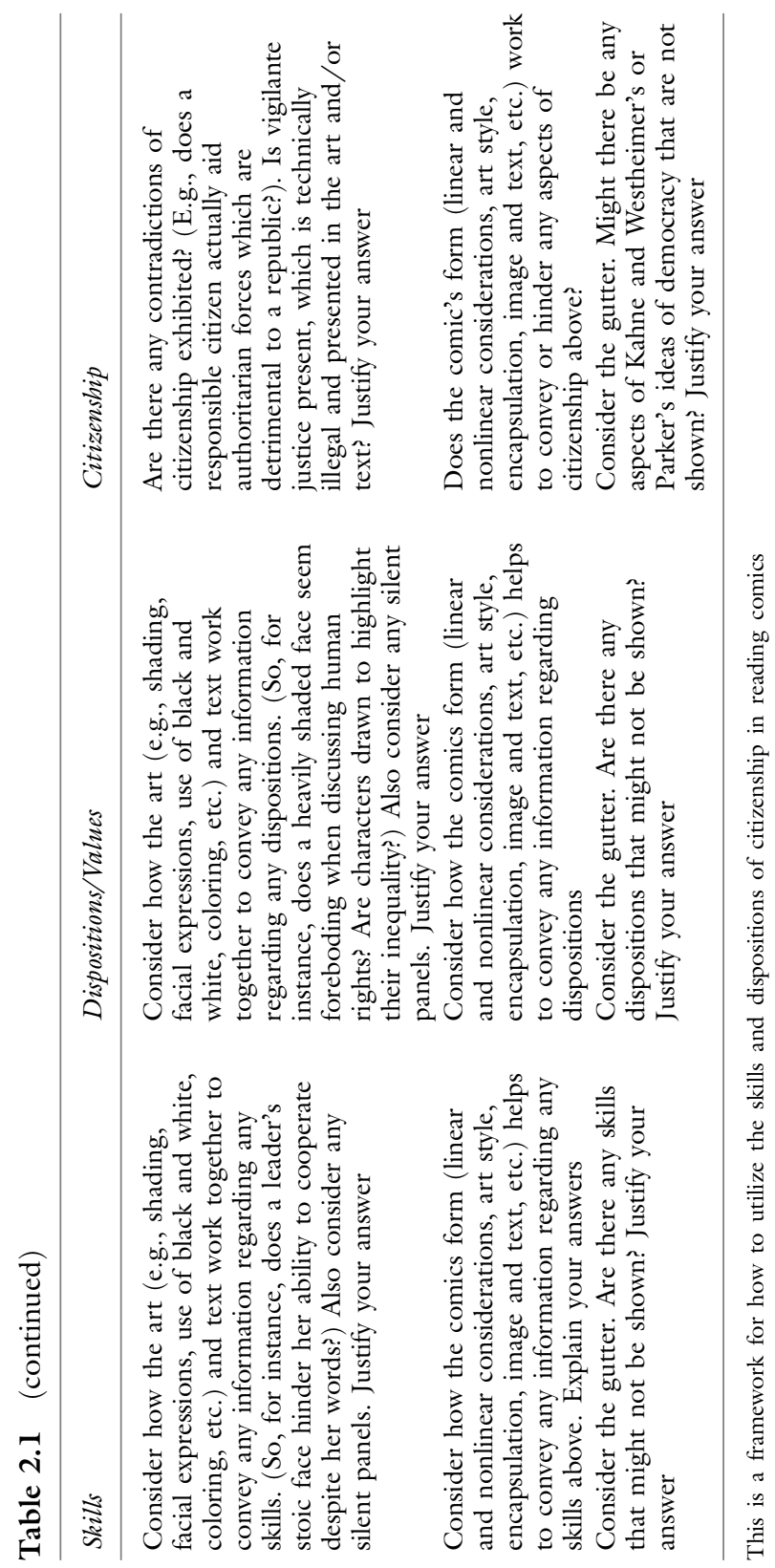


Does this comic offer any nonlinear readings? Are there any creative reading patterns or use of multilinearity? What types of meanings do these alternate readings convey?

There is a great comic called Hunter/Prey (1994) by Dan Jurgens and Brett Breeding. This comic is a rematch of Superman and his archnemesis Doomsday, who had killed him years before in the famous Death of Superman comic. Both Superman and Doomsday returned to life. This comic gives Doomsday's harrowing back story. Scientists deposit a baby out in the harsh environment to watch the baby die. They collect the remains, use the genetic material, and create a new baby to repeat this process. The purpose of the grisly experiment is to create a perfect being, one that cannot be killed. The scientists succeed, only to be killed by their own creation. I believe this scene could be related to citizenship questions. When I read this, I wanted to know what else these scientists were thinking. What values and dispositions did these scientists hold? What did they go home and say to their wives and husbands about their work? Was this rationalized in the name of progress and science? What would an outsider think of this? How did the art and features of the comics medium help to convey this story in ways that text alone could accomplish? A student could be asked to reconstruct a scene like this. A nonfiction comic could be used as well. For instance, students can be asked to think about what more information they would like to know about abolitionists or what Abe Lincoln was thinking to himself or told his wife in moments not shown in the comics. The questions of what is not known or cannot be seen in the comic can be an important process for grappling with citizenship.

\section{The NCSS Standards/Disciplines of the Social STUdies}

The National Council for Social Studies (2020) is a professional social studies organization which publishes standards and resources for schools and practitioners of the social studies. The website reads: "NCSS serves as an umbrella organization for elementary, secondary, and college teachers of history, civics, geography, economics, political science, sociology, psychology, anthropology, and law-related education." Membership includes K-12 teachers and university professors and others.

NCSS has created ten themes which help to guide social studies instruction in classrooms. Essentially, the themes articulate what should 
take place in social studies programs. Further, the standards "represent a way of organizing knowledge about the human experience in the world" (NCSS website). Some more progressive scholars have argued the NCSS themes are generic (Ross, Mathison, \& Vinson, 2014). While they are generic, I like the fact that they call attention to the diverse disciplines that make up the social studies, from history to psychology, economics, political science, geography, and anthropology (Chapin, 2015). I have created assignments that aligned with the classes that I was teaching, particularly history, psychology, and law. I did this because I know these bodies of knowledge and because it was convenient. My assignments however are not exhaustive. I challenge social studies teachers and professors in a variety of disciplines to build on my work and create more discipline specific assignments that involve citizenship and the comics medium (Table 2.2).

The chart calls for students to look for evidence of these themes in graphic novels. This is an example of students bringing social studies theories to bear on graphic novels. Again, the chart does not have to be answered in its entirety, its main purpose is really to spark a discussion. For instance, if this chart were to be used with the graphic novel Persepolis by Marjane Satrapi, which details the authors struggles growing up at the time of the Islamic Revolution in Iran, it could be argued that certain themes and disciplines from the chart are present. For one, the revolution itself obviously is emblematic of the sixth theme, power, and authority. The graphic novel heavily centers on Iranian culture, so the first theme is present as well. In addition, there is also some discussion of capitalism, so the seventh theme of production and consumption is also present. Likewise, different disciplines could be used to understand the events of the graphic novel, from a historical consideration of the revolution, to a geographic consideration of Iran, as well as an economic examination of the country and the relation of capitalism to the revolution. Further, teachers and students can discuss how the notions above are further enhanced by the use of a graphic novel and how the features of the graphic novel help to convey historical events in different ways.

The National Council for Social Studies also published the C3 or College, Career, and Civic Life framework. This framework promotes inquiry as an important part of the social studies (Larson, 2017). The C3 framework also builds on the Common Core Standards in the Social Studies (Larson, 2017). While the exercises in this book are not necessarily inquiry based, they can help to fulfill one important component of the inquiry process: the gathering and use of evidence to make decisions. 
Table 2.2 NCSS standards assignment

\begin{tabular}{|c|c|}
\hline NCSS themes & Disciplines of the social studies \\
\hline Culture & History \\
\hline Continuity & Political Science \\
\hline Environments & Geography \\
\hline Identity & Economics \\
\hline Individuals and groups & Psychology \\
\hline Power and authority & Anthropology \\
\hline Production and consumption & Sociology \\
\hline Science and technology & ${ }^{*}$ not an exhaustive list \\
\hline \multirow{2}{*}{\multicolumn{2}{|c|}{$\begin{array}{l}\text { Global connections } \\
\text { Civics }\end{array}$}} \\
\hline & \\
\hline $\begin{array}{l}\text { Are any of the themes present in any } \\
\text { form in the graphic novel? }\end{array}$ & $\begin{array}{l}\text { Are any of the disciplines present in any } \\
\text { form in the graphic novel? Think here } \\
\text { of what comprises each discipline. } \\
\text { Justify your answer }\end{array}$ \\
\hline $\begin{array}{l}\text { Consider how the comics form (linear } \\
\text { and nonlinear considerations, art style, } \\
\text { encapsulation, etc.) work to convey or } \\
\text { exhibit any of the themes above }\end{array}$ & $\begin{array}{l}\text { Consider how the comic form (linear } \\
\text { and nonlinear considerations, art style, } \\
\text { encapsulation, etc.) works to convey or } \\
\text { exhibit any of the disciplines above }\end{array}$ \\
\hline $\begin{array}{l}\text { Is anything present in the graphic novel } \\
\text { which may point to a theme which is } \\
\text { not on the list above? }\end{array}$ & $\begin{array}{l}\text { Does the graphic novel offer any } \\
\text { different viewpoints of the material that } \\
\text { you have learned from other sources? }\end{array}$ \\
\hline $\begin{array}{l}\text { How does this graphic novel's treatment } \\
\text { of any material differ from any other } \\
\text { graphic novels you have read on our } \\
\text { own or have been assigned? }\end{array}$ & $\begin{array}{l}\text { How might anything you read be linked } \\
\text { to other disciplines and subjects you } \\
\text { study in school, such as the sciences, } \\
\text { mathematics, physical education and so } \\
\text { on? }\end{array}$ \\
\hline $\begin{array}{l}\text { If the graphic novel is recent, is } \\
\text { anything about the art, text, or art-text } \\
\text { combination political or partisan? Does } \\
\text { it seem to endorse or discredit any } \\
\text { current political beliefs? Further, can any } \\
\text { of these beliefs be tied into the NCSS } \\
\text { themes? }\end{array}$ & $\begin{array}{l}\text { If the graphic novel is recent, is } \\
\text { anything about the art, text, or art-text } \\
\text { combination political or partisan? Does } \\
\text { it seem to endorse or discredit any } \\
\text { current political beliefs? Further, can any } \\
\text { of these beliefs be tied into any of the } \\
\text { social studies disciplines? }\end{array}$ \\
\hline
\end{tabular}

Whenever students make an argument about a comic or graphic novel, they must provide evidence and back up their points with evidence. So, for instance, a student cannot just say that a Superman comic exhibits the skills and dispositions of citizenship, but must collect evidence and examples and show this to be the case. Teachers can highlight this evidence gathering feature of the assignments in this book. 
The social studies largely consists of the discipline of history, and the behavioral and social sciences, such as psychology, anthropology, sociology, and the study of the law (Chapin, 2015; Larson, 2017; Zevin, 2000). As Zevin $(2000,22)$ notes: "social studies draws from many sources to achieve its goals." In my own social studies methods classes, we speak a great deal about the different disciplines of the social studies and the NCSS themes.

I assigned this framework to my social studies methods class. I distributed a number of graphic novels and had students read through them. This activity was done on the day that we as a class discussed in detail the disciplines that make up the social studies. I think it important to focus students not just on the content of the graphic novels, but also the comics form in relation to the disciplines. We discussed in detail the graphic novels Maus, The Sacrifice by Bruce Mutard, Gettysburg, and Joe Sacco's Safe Area Gorazade. I found one of the most insightful observations when one of my students compared Safe Area Gorazde to Maus and noted how in Maus there is a visible difference between the characters because of the animals used to portray them, but how in Gorazde, the people were drawn similar. She wondered if this was maybe the intention, to show that people in Bosnia were not that different. I thought this a very prescient remark and evidence of how not just the content but the comics form can help students in their interpretations. This remark also touched on some of the different disciplines of the social studies (psychology, sociology) and NCSS themes (groups, identity).

Psychology is obviously important to the study of citizenship. The fourth NCSS theme, individual development and identity, deals in part with psychology (Chapin, 2015). I taught Educational Psychology for graduate students at my university (during the Spring of 2019) and so I have some firsthand teaching knowledge of psychological theories. Chapin (2015) notes the popularity of psychology courses in high school. A good portion of high school students participate in psychology electives. So the frameworks can be employed with a number of classes and age ranges. The frameworks could also be employed in a history class (I used historical material) to highlight how psychological concerns are present in the study of history. One critical question that psychology can help shed some light on, and which is crucial for understanding citizenship, is the process by which human beings come to hold certain beliefs and values, and how those beliefs and values lead to actions for both individuals and 
groups (Shealy, 2014). Understanding which values are right or wrong is not necessarily the point. Rather, as Shealy $(2014,3)$ goes on to note:

Much more important is understanding the complex interactions (e.g., among affect, cognition, context, culture, and development) that culminate in a unique constellation of beliefs and values for every human being, as well as how and why these different versions of reality inevitably are linked to the actions, practices, and policies of individuals, groups, organizations, governments and societies all over the world.

This is a powerful statement and one that I think cuts to the heart of psychology and citizenship, specifically the notion of a version or reality. We as a society need to understand how beliefs and values impact human behavior and actions (Shealy, 2014). The way human beings come to hold these beliefs and values is a combination of "our unique developmental, life and contextual experiences, which interact with powerful affective and attributional processes that are neurologically mediated, and of which we may have little awareness" (Shealy, 2014, 14). Shealy then goes on to note that while psychology is important in understanding this process, that the contributions from other disciplines and fields as well as "theory, data and analyses that transcend any specific domain" $(2014,14)$ will be necessary to truly understand beliefs and values. I think that the comics medium can be a beneficial way to explore the notion of a VOR. This concept of a version of reality (VOR) I think lends itself particularly well to both reading and creating comics because a student can begin to see a VOR and actually chart the creation of their own VOR in visual form.

The last question has students actually drawing a quick mini-comic. I present a student example of this question in Chapter 4. This is a good reminder that both comic reading and comic creating activities can be done at the same time and overlap. I have chosen to artificially divide them up for the structure of this book. In addition, when I originally gave this assignment, I did not have question three. I added this after. Prior to implementing this activity, I had given my students excerpts from Shealy's (2014) work and excerpts from graphic novels. The first excerpt came from March, which centers on the story of John Lewis, the current congressman from Atlanta, and his association with SNCC and the Civil Rights movement. The second excerpt came from and older Marvel comic, Gettysburg, which depicts the Battle of Gettysburg. 


\section{Comic VOR Activity}

Directions: Answer the questions below.

1. Try to construct the VOR for the two types of opposing characters depicted on the page. Consider how each character (and the groups they belong to) came to hold these beliefs and values, and how the character's VOR (Shealy, 2014) may have led him or her to the actions depicted on the page.

2. Consider the actions being depicted. How did the artist depict actions? (Consider here the use of sequence, color, shading, lines, facial expressions, linear and nonlinear considerations, emotions and gestures as well as what is shown and what is not shown.) How does (might?) the art help to understand the actions on the page and perhaps the beliefs that led to those actions, for both the individuals and larger groups?

3. What bias may have been present for the creators? Do you believe the representation of the subject matter is biased in any way? Justify your answer.

4. Consider your own VOR. Try to construct it, reflect on how your own VOR impacts your behavior (try to be specific). Now actually depict this visually with sequential art. Use sequential art to show how your VOR might induce actions (see the professors example).

This assignment generated what I thought was some great conversation. Of course I was not totally satisfied with its implementation. Some students felt a little bewildered and were unsure of what I was asking. I learned I need to be clear on these types of assignments. However, overall I was pleased. I had a class of about 18 students and had them work in groups of two to four people. I made sure to talk with each group privately, and then hold a class discussion. I believe this way generates more discussion because people may not open up in front of a class, but people may open up in small groups. We discussed what a VOR is and how it may be created. Admittedly, I stacked the deck a little by selecting two episodes (The US Civil War and the Civil Rights movement) which had an obvious and deadly clash of values (I also considered using Maus, but wanted to introduce the students to some comic's series they may not have been familiar with). But that was the point. I wanted students to see this clash, not just read about it. I also felt that the VOR assignment 
aligned with the fourth NCSS theme of identity development. When I spoke with students in their groups, and then in the overall class discussion, we were able to theorize about the VOR's of the different characters and groups in the excerpts (e.g., Civil Rights protestors and Southern police forces, or Northern and Southern armies) and how sequential art helped to depict some of these ideas. I also drew a portion of my own VOR to show the class what I wanted them to do. I believe this example helped tremendously.

I greatly simplified Shealy's (2014) complex body of work. I did not touch on a number of important points that are central to his work. My main interest was to look at how beliefs drive actions. Instructors could delve deeper into his body of work and create more detailed assignments. I believe that the assignments I created worked well for my classes.

The next two assignments dealt directly with topics that we covered in our textbook (We use the text Educational Psychology, 14th edition, by Anita Woolfork, 2016). Specifically, we read about ELL and refugee students and students with epilepsy and the psychological concerns of educating each group. The two graphic novels I chose were Epileptic, by David B., and Illegal by Chris Coffer. Epileptic centers on the story of David, whose brother is an epileptic, and the trials his family faces because of his brother's illness (Wolk, 2007). Illegal centers on the story of a young boy and his brother who are trying to escape an African nation and make it to Europe. While these topics were specific to my Human Development and Learning course, they nevertheless could be a bridge to wider topics, such as racism, ethnocentrism, and disability. The attitudes we hold toward other people and the actions we take, the ideas we hold about ourselves resulting from our own cultural orientations, and the way we interact with others are psychological and citizenship questions. As pointed out in the introduction, some excellent work has been done on related topics such as disability in comics (Whalen, Foss, \& Gray, 2016), cultural concerns, and stereotypes in comics (Cook \& Frey, 2017; Dong, 2013 ) to name a few examples.

My aim here was to discuss the content of the graphic novels and how it was represented in the medium of comics. We analyzed the art and looked at how the comics form may have helped to convey these ideas in new and novel ways. We then discussed the intersection between psychological phenomena and social occurrences, as well as how teachers (since my students are current and prospective teachers) might grapple 
with these issues in their classes. Our discussion reflected many of these concerns.

Read the excerpt from the Graphic Novel titled: Illegal

1. From what you can tell, what is going on in both sequences? Consider what is shown. Consider the interplay between image and text.

2. What are some of the cognitive and affective impacts of the sequence?

3. How does the material in the excerpts align with the information in the textbook?

4. How might this different, nonacademic view of this material compliment the information in the textbook?

5 . What might be some implications for teaching?

6. What might be the intersection between what we know from psychology and global policies and conditions?

Read the excerpt from the Graphic Novel titled: Epileptic

1. From what you can tell, what is going on in the sequence? Consider what is shown. Consider the interplay between image and text.

2. What are some of the cognitive and affective impacts of the sequence?

3. How does the material in the excerpts align with the information in the textbook?

4. How might this different, nonacademic view of this material compliment the information in the textbook?

5. What might be some implications for teaching?

6. How might epilepsy, and disability in general, be understood from a psychological and political/social frame?

\section{LAW AND CIVICS}

Another area where comics can be used is in the study of case law. Case law could obviously fall into the history curriculum. In addition, as noted earlier, the NCSS "About Us" page notes the standards can be used by teachers at all levels of "law-related education." The study of law can relate to the sixth NCSS theme, "power, authority and governance." 
I used the activity below in my law class with doctoral students. While the main thrust of this assignment dealt with disability case law and legislation, in previous weeks we had also spent a great deal of time examining Title IX legislation. So, I thought the Barbara Gordon/Batgirl/Oracle debate was a natural fit. I first gave the students an excerpt from Alaniz (2016) who chronicled the controversy surrounding Barbara Gordon. I then gave my students an excerpt from the Killing Joke (the scene where Barbara is shot) as well as a scene from a later comic where Oracle is assisting Batman in crime fighting in her wheelchair. Barbara Gordon was put in a wheelchair after Joker viciously shot her in The Killing Joke. She then became the hero and super hacker Oracle, a powerful superhero in her own right (Alaniz, 2016). Yet, in 2011, DC updated the story for the New 52 series, and facilitated a "de-disabling" of Barbara (Alaniz, $2016,60)$. She would be Batgirl, with the use of her legs, again. Some celebrated this move because of what many see as the pervasive violence against women in comics. Many thought Barbara should not be disabled. Yet, many also saw Oracle as a powerful icon, a person with disability who was a superheroine. So, I used this controversy to dissect issues of gender and disability. I was able to relate these wider ideas to our discussions of policy and case law.

\section{Title IX and Disability Assignment}

Directions: Read and answer the questions

1. Read the except from Alaniz (2016) and summarize the controversy surrounding Barbara Gordon/Batgirl/Oracle.

a. In what ways might this controversy echo some concerns that you have read about regarding disability legislation?

2. How might the art and text on the comic pages help to portray some of the issues regarding disability legislation as well as Title IX concerns we have read and spoke about?

a. Consider the panel size, line work, facial expressions, depicted actions, and/or word balloons.

3. Consider disability from a citizenship and common good perspective. 
a. What implications might disability have on our understanding citizenship and the common good (Dayton, 2012)?

b. How might the Oracle/Batgirl/Barbara Gordon issue help to better illuminate these issues?

One student detected eugenic strains in the comics. Another student, looking at the excerpt containing Oracle in a wheelchair, noted how it almost seemed like she was in a position of power because Batman was asking her for information. Another student was quick to point out however that she did call him boss. We were able to talk about representations of people with disabilities and stereotypes. Again, like the psychology exercises I included, this exercise was specific to my course content. However, disability in comics is a pertinent issue (Garland-Thompson, 2016) and can be used to open discussions on a wide range of citizenship issues from discrimination to policy.

\section{Mythology}

I do not think it a stretch to say that most students are required to study mythology and religion. Most students probably study Greek and Roman mythology, but also perhaps Sumerian and other cultures as well. So a discussion on mythology can be very fruitful and aligns with many types of required social studies knowledge. I also think the study of mythology aligns with the hyperreal, which I will attend to shortly.

Cook and Frey, drawing on a number of scholars $(2017,1)$ as well as Novak $(2014,8)$ argue that comics books and superheroes are our "modern mythology" (Halsall, 2018). Cook and Frey (2017, 1) argue that our superheroes, like Odysseus and Beowulf before them "are meant to resonate within their cultures," and are products of the environments from which they came. Novak (2014) also posits that the most important parallel between comics and ancient mythology is the ability of comics to understand ourselves and society.

But what is a myth? Vandiver $(2000 \mathrm{a}, 6)$ offers this definition: "traditional stories a society tells itself that encode or represent the worldviews, beliefs, principles, and often fears of that society." Typically, myths "explain, justify, instructor or warn" (Vandiver, 2000a, 23). Myths can explain the reasons for things, justify a condition, show people how to act, or warn people about something. Later scholars such as Freud and Jung 
saw myths as psychological phenomena. For Freud, myths become the "collective dreams of the human race," and Jung saw myths as containing "archetypes or recurrent images that exist cross culturally and throughout time" (Vandiver, 2000a, 39). Vandiver (2000a) argues that while all of these theories have something useful to offer, they all may be lacking as well. Instead, she uses the theories above as tools to understand myths when appropriate (Vandiver, 2000a). Vandiver (2000a) also points to the important of understanding myths in their historical context.

Vandiver (2000b) also examines the mythmaking impulse in the present. Of course, mythmaking in present America is much different than Ancient Greece or Sumer (Vandiver, 2000b). She argues that now, mythmaking is flipped. We cannot believe in fantastic races of the past because we understand our history and geography, we largely know what happened. Vandiver (2000b) argues that we now see our heroes in the future. She $(2000 a, b)$ notes that these characters are not our ancestors. Rather, they are our descendants. Modern audiences may also now have a familiarity with 2500 years of myths. In the stories of the future, we recognize mythic themes that we have seen in the myths of the last 2500 years (Vandiver, 2000b).

Following this line of thought, I think certain comics can accomplish this mythmaking function. I think the potential is great for comics to act as a way to study myth and as a mythmaking vehicle (the mythmaking exercises will be examined in Chapter 4 ). Another question we must ask ourselves is what is the relation of ancient myths, modern mythmaking in comics' form, and the hyperreal? If you have been paying attention this far, this question cuts to the heart of this book. Both existing myths and the creation of new myths can be important devices in hyperreality. Citizens can examine some of the ideas behind existing myths and the mythmaking impulse to truly understand myth and how to utilize them in hyperreality. The directions call for students to think critically about how the comics medium helps to convey important information in different and unique ways (e.g., multilinearity, word balloons).

Teachers can begin with existing myths and then extend this to the present. Myths are not simply for ancient people or people living in the remote past. Myths are possessed by all cultures (Vandiver, 2000a). Teachers can link the study of traditional myths (which as noted above is usually on a variety of state curriculums) to the mythmaking impulse that is still alive and well, albeit which may look a little different. Below are assignments in which students analyze the traditional myths as well as modern 
myths found in comics. Students then compare them to ancient myths using Vandiver's (2000a, b) ideas. As with most of the assignments in this book, the teacher will have to decide on certain parameters. The most obvious one is whose mythology to study. In my own experience from teaching Ancient World History, I had to cover Sumerian, Egyptian, Greco-Roman, and Aztec mythology. So, for simplicities sake, let's stay with Greco-Roman myths. Another consideration is graphic adaptations of myths. Certain myths are now in graphic novel form. Gareth Hinds has created an excellent adaption of Beowulf and The Odyssey. Carter (2011) argues that examining the same story in two different mediums can lead to fruitful discussions about different choices different creators make in the different renditions of the story. Following this, I have students looking at the same story in different mediums (graphic novel and traditional print text). Obviously, not all myths are in graphic novel form so the first assignment can only be done with graphic adaptations. Teachers will also have to decide how much of a story (both the traditional myths and the comics) students will read. Finally, teachers will have to give some instruction on Vandiver's (2000a, b) ideas (Table 2.3).

For the second assignment, the teacher will have to decide if students will have free reign to choose what comics to study, or if teachers will select stories for students to look at. Halsall (2018) argues for reading classic texts alongside of graphic novels. Halsall $(2018,93)$ notes: "A graphic novel thus possesses a crossover ability to inspire deep and passionate responses from readers in the reading of canonical classics." Halsall (2018) had students look at a traditional version of the Odyssey and Frank Miller's 300, two different stories. The assignment below has students looking at a traditional story, such as the Odyssey, and a modern myth that either students or teacher and students as a class identify as such. An excellent starting point may be Robert Kirkman's The Walking Dead which I use as an example. Of course all stories may not be suitable for some students, so teachers could adjust as necessary. Portions of The Walking Dead are definitely not suitable for high school students. This exercise could also be done in conjunction with the above exercise or as a standalone exercise. I have also added a question on heroes. As Vandiver (2000b) notes, the heroes of ancient myths are not always good or morally upstanding, in fact many commit some terrible actions. One conception of hero just entails that a person has done extraordinary, and not necessarily, good, things (Vandiver, 2000b). Negan, a dictator type in this post-apocalyptic world in the Walking Dead series, may be 
Table 2.3 Mythology assignment 1

Directions: Read the excerpts from Hinds The Odyssey. Fill in the chart below as you read

1. Briefly describe the historical context of the myth. From which conditions did it emerge?

2. Compare the graphic adaptation to the traditional written text. What are some differences and similarities?

3 . What are the advantages and disadvantages to each medium at portraying the myth? Justify your answers

4. What purposes might this myth have served for the ancient Greeks?

\begin{tabular}{|c|c|c|c|}
\hline Myth lens & Examples & $\begin{array}{l}\text { How does the features } \\
\text { of the comic form help } \\
\text { to convey these ideas? }\end{array}$ & $\begin{array}{l}\text { Can you make a case } \\
\text { for any aspect of the } \\
\text { myth, especially one } \\
\text { represented in comics } \\
\text { form, resonating with } \\
\text { modern audiences? } \\
\text { Justify your answer }\end{array}$ \\
\hline
\end{tabular}

Explicative (Does

anything in this myth

explain something?)

Justification (Does

the myth justify a

situation?)

Instruct (Does the myth instruct people

how to live?)

Warning (Does the

myth warn about

something?)

Psychological (Does

anything in this myth

tell us about ourselves

or society?)

considered a type of a hero. Even Rick, the protagonist, does some very questionable things. Deciding who is a hero can be a fruitful exercise not just for the text, but also from a social studies standpoint. There are many people in the past who may have done extraordinary, but morally questionable acts. Students can get their hands dirty with this question. The last column on the chart links this exercise back to the traditional (and usually curriculum based) study of myth. Teachers may want to give students time to complete this individually, in groups and then as a class 
discussion led by the teacher (Table 2.4). In addition, I assigned a variation of the assignment below to my own children when I homeschooled them during the COVID-19 crisis.

\section{Prior Knowledge and Emotional Context}

One crucial action that teachers can do to enhance student teaching is to relate new material to something students have already learned (Larson, 2017; Woolfork, 2016). Woolfork $(2016,324)$ asserts "we use old knowledge to understand the new." However, as Larson (2017) also points out, student misconceptions must be addressed as well.

Here, graphic novels which relate to historical topics can fulfill this function. So, if students are studying the American Civil War, specifically the Battle of Gettysburg, teachers could first present traditional material on Gettysburg such as lectures, videos, and group work. After a few lessons, teachers could introduce a graphic novel relating to Gettysburg. The point here is to be very deliberate and show the connections (or better yet, guide students to enumerate them) between the graphic novel and the more traditional material learned in class. Teachers can help students to activate their prior learning (and misconceptions) regarding the Civil War and the Battle of Gettysburg with the graphic novel. The graphic novel offers a further boon to activating prior material, the comics medium itself. The representation of the Battle of Gettysburg in graphic format is obviously very different than its presentation in a textbook.

The representation in different forms can lead to another facet to this assignment: emotional and personal context. Something I try to promote with my law students is that the law, while abstract, is also very personal. The plaintiffs and defendants, while seemingly abstract entities on paper, are real flesh and blood people. Similarly, policies, while abstract and jargon laden, impact real people. Reading a graphic novel, with a focus not just on the theories and facts, but on the emotional contexts, may help to convey this aspect of policy and case law and history in general.

In my education law class, we study Brown vs. Board of Education (both Brown I and Brown II) as well as the Green v. County School Board of New Kent County case, and part of the Civil Rights Act. These are obviously landmark rulings and policies which impacted millions of people and continue to impact later generations. We first study these cases and policies in a more traditional way. Students read them from a text and we discuss them in class. However, in an online module, I then assign relevant excerpts from the graphic novel March. Student's see a different 
Table 2.4 Mythology 2 assignment

Directions: Read excerpts from Robert Kirkman's The Walking Dead and fill in the chart and questions as you read

1. How does this "myth" compare with the traditional myth you read?

2. Who would you consider heroes in this story? Justify your answer

\begin{tabular}{llll}
\hline Myth lens & How does & Consider & Who are the \\
& the features & what is shown heroes and \\
& of the comic and not & how are they \\
form help to shown. What portrayed with & convey these else could the comics \\
& ideas? & have been & form? \\
& shown to \\
& convey these \\
& ideas? Justify \\
& your answer
\end{tabular}

Explicative (Does

anything in this

myth explain

something?)

Justification (Does

the myth justify a

situation?)

Instruct (Does the myth instruct people how to live?)

Warning (Does the myth warn about something?)

Psychological (Does anything in this myth tell us about ourselves or society?)

Familiarity (Are there any elements in this story which resemble the myths we have read?)

Historical/Modern

Context (What

elements of our time period may have inspired the writing of this myth?) 
angle here than what they read about. I assigned this activity to my education law class. I assigned it online and we discussed it the next week in person. I think the utilization of online platforms also speaks to the importance of fostering media literacy and familiarity with digital modes of expression for students.

\section{Prior Knowledge and Emotions Assignment}

Directions: Answer the questions below

1. Write a brief summary of the impact of the Brown and Green decisions, as well as the Civil Rights Act of 1964 and Voting Rights Act of 1965.

2. Examine the excerpt. What new information does this excerpt convey?

3. Specifically attend to the features of the graphic novel (panel size, encapsulation). How do these features help to convey the information? What can the graphic novel not tell you, or what might be difficult to convey? (Below are some features to consider)
a. Panel size
b. Encapsulation
c. Sequencing/sequential art
d. Nonlinear considerations
e. Creative reading patterns
f. Multilinearity considerations.

4. Specifically concentrate on the emotional context.

a. What gestures and/or emotions are represented from the various characters depicted?

b. What kind of information does the emotional context convey about the situation?

5. What type of understanding do you gain by reading the graphic novel in conjunction with the traditional text?

\section{Prior KNowledge ANd EMotional Context Assignment}

Pedagogical note: In the assignment above, I have combined two aspects into one assignment: prior knowledge and emotional context. However, 
Table 2.5 Prior knowledge assignment

\begin{tabular}{|l|l|l|}
\hline Knowledge of Topic & Knowledge you gained from comic & $\begin{array}{l}\text { How the comic medium helps to portray } \\
\text { this knowledge }\end{array}$ \\
\hline & & \\
\hline & & \\
\hline & & \\
\hline
\end{tabular}

teachers could eliminate question four and simply focus on prior knowledge if the teacher feels that the assignment is asking too much. The exercise below focuses specifically on prior knowledge. This exercise should be done with historical graphic novels. The left side of the chart calls for students to write about what they learned on a topic. The middle column has students compare this with a comic. So, if students are given a lecture and some worksheets pertaining to the Holocaust, the next week they can read selections of Maus. It may make sense to have students complete the left hand column before they read the excerpts. The last column specifically pertains to the comics medium and forces students to consider how the comics medium differs from traditional text. The cheat sheet in the beginning of this chapter can be utilized as well (Table 2.5).

\section{Global Citizenship}

Many great civilizations past and present, Western and non-Western, have enumerated powerful political ideas. Kincheloe $(2001,41)$ notes that we have much to learn from "African insights, Asian intellectual and theological traditions and the ways of seeing of indigenous peoples." These nonWestern perspectives can enhance Western notions which are based on rationality to the detriment of other forms of knowing (Kincheloe, 2001). Obviously, I cannot cover all of them, or even most of them. I will mainly focus on Buddhism. In this chapter I discuss notions that I believe all people can practice and pursue, and in Chapter 3 I discuss ideas that are more for policy-makers and leaders. Of course, there is a great deal of overlap between the two chapters and both sets of ideas can inform each other.

Moore $(2015,36)$ notes that Buddhism "is distinct from Western theories and poses a plausible and attractive alternative to them." Following this sentiment, I think Buddhism may give students and teachers new insights to utilize when grappling with citizenship, especially in hyperreality. Jacobson $(1983,4)$, writing in the early eighties but whose words are no less relevant now asserts that Buddhism may be "the only viable 
alternative" to the turbulence and volatility we presently find ourselves in. I agree. We as a species are currently locked into destructive modes of thought and action which threaten the entire planet (Jacobson, 1983). A study of the political ideas of Buddhism, situated in the backdrop of hyperreality and facilitated with the use of graphic novels, may offer use unique insights into this situation. Students can begin to see how Buddhism is presented or they can look for Buddhist ideas and argue for their presence.

Buddhism originated with Siddhartha Gautama, who lived in India from 566 BCE until 486 BCE. Siddhartha was born into wealth and royalty, and was said to be destined to be a great political or religious leader. Siddhartha lived a comfortable life in the confines of his palace. But he became curious and ventured outside the walls where he saw "an old man, a sick man, and a corpse" (Eckel, 2010, 8). Another time, he saw an ascetic and finally vowed to be like the ascetic, against the wishes of his father. Siddhartha wanted to find an answer to the question suffering (Eckel, 2001, 2010; Kessler, 2001). He wandered as an ascetic but eventually felt that this was not the way (and almost died of hunger). Finally, Siddhartha had an awakening and realized the nature of suffering and how to free oneself from this suffering. This awakening consisted of the realization of the Four Noble Truths. These were: "the truth of suffering, the truth of the origin of suffering, the truth of the cessation of suffering and the truth of the path" (Eckel, 2010, 89). Life is marked by suffering and this suffering is caused by desire. To end suffering, one had to end desire. Once desire was fully extinguished, suffering would end in the state of nirvana, "which means literally to 'blow out' the fire of ignorance and desire" (Eckel, 2010, 90). Hanh (2017) also stresses that Nirvana is not something to be achieved after death, but can be achieved in the present. In addition, Buddhism adapted the notions of reincarnation and karma from Hinduism, the religion from which Buddhism was founded (Moore, 2016). A number of different schools of Buddhist thought rose after Siddhartha's death, the Theravada and later the Mahayana being two of them (Eckel, 2001).

One fundamental pillar of Western thought is the belief that society consists of "independent rational individuals whose autonomy and subjectivity must be respected by the political system for that system to be legitimate" (Moore, 2015, 43). In contradistinction to many Western theories, Buddhists posit a theory of no self, or the anatta doctrine, which does not see the individual as a discreet entity (Moore, 2015). Eckel $(2010,60)$ 
asserts that to be considered wise one must "see that the self changes at every moment and has no permanent identity." Moreover, Moore (2015) argues that the individual is merely an illusion, and to cling to the self as a discrete entity is damaging. Jacobson (1983) likens the self to a prison and an illusion. The notion of a self verses a nonself is a dualism that has persisted in Western thought for centuries along with other dualisms such as mind and matter, life and death and so on (Jacobson, 1983, 7, 95). Please note that many Buddhist scholars have debated the no-self doctrine (Moore, 2015) and I have only scratched the surface here.

The paticca-samuppada which is another important Buddhist doctrine, denies the substance of things. In this view, the moments in the process of life "depends upon every preceding moment for its emergence, and the passing moment with its new choices and possibilities 'originates' the next" (1983, 43). From this movement, the many become one (1983). Moore $(2016,8)$ notes about the paticca-samuppada: "Everything is related to everything...this teaching reinforces the idea that there is no self." Further, when we cling to things we think are permanent, (even ourselves) but which really are transitory, we suffer (Jacobson, 1983; Moore, 2016). Eckel (2001) contends that while this formulation of the self as impermanent may seem pessimistic, it actually has great promise. We as humans suffer not due to change, but because we cling to things and want them not to change. Eckel $(2001,25)$ notes: "if everything changes, then it is possible for everything to become new." What an insight! We want permanence in a reality of impermanence and fail to see that possibility of newness. Even our very selves, the vaunted individual, must give way to change.

It should be stressed that the no-self doctrine does not diminish the concern for individual life or human rights (King, 2009). Buddhists affirm the importance of individual life. However, this view does not place a high emphasis on "a strongly individualistic society" (such as in the United States) but rather emphasizes a more communitarian conception of society and the relations of individuals to the wider world (King, 2009, 22).

The ideas of no-self and paticca-samuppada can be used as a counterpoint to one of the sacred cows of Western political theory-the self and its role in a republic. What might our political discourse sound like without a preoccupation with individual rights? How might citizens utilize the optimism of the no-self doctrine in political discourse? How might the comics medium be used to showcase the idea of no-self and its political implications? 
Another area of distinction between Buddhism and most political thinkers in the West is the actual role of government and politics. Moore stresses that governmental systems and politics do have a role in Buddhist thought, but they are not central. A good political system may be able to help people come to salvation, but it is not necessary (Moore, 2015, 2016). This is the notion of limited citizenship, which Moore situates the Buddha in. Limited citizenship essentially entails participating in politics as far as necessary (e.g., doing your duties such as paying taxes and following law, and participating more actively in emergencies when necessary) but overall, "politics are largely a distraction from the important things in life" (Moore, 2016, 96). Moore stresses that neither the active political theories nor the limited citizenship theories are correct, it comes down to a judgement call.

The notion of limited citizenship may offer a rich discussion piece for a social studies class, as it forms a counterpoint to much of the active political theories espoused in the West (and many of the ideas discussed in Chapter 1). As a social studies teacher, and reared in the Western tradition, especially in America, politics is at the forefront. However, the notions of limited citizenship, while not better or worse, just different, can get students thinking about the role of politics and government in their own lives and society in general. How active should we be in politics? What is the role of a political system in the pursuit of spiritual development and happiness? These questions, posed with Buddhist thought, can augment any discussion of citizenship.

Of course, there is a great tradition of political engagement throughout the history of Buddhism (Eckel, 2001). There is also the modern notion of socially engaged Buddhism which emerged in the twentieth century and connects Buddhist practices to social issues (Barclay, 2019; King, 2009). It is a nonviolent, non-centralized movement which cuts across different Buddhist denominations, and it stretches to the West. There is no one single leader of engaged Buddhism. The Dalai Lama and the Vietnamese monk Thich Nhat Hanh are two prominent advocates (King, 2009). While I will briefly explore some of their ideas, The Dalai Lama and Thich Nhat Hanh, and really all major advocates of engaged Buddhism, are just too impactful and insightful to be fully represented in this short section. I have selected some nuggets of their wisdom which I think are of use to the study of citizenship.

For true change to occur "shouting and complaining is not good enough" (Gyatso, 2001, 40). We cannot just blame politicians and wash 
our hands - the true change must come from within the self (Gyatso, 2001). Politicians, corporations, and UN can only achieve so much. The Dalai Lama urges individuals to act, but in the process of acting, individuals should not play "the blame game," they should respect differences, and never coerce (Gyatso \& Stril-Rever, 2017, 83). This is a powerful idea-people must act and not simply expect politicians to enact change for them. This conception of action can add a new dimension to a discussion of representative government and citizenship in a republic in general. While we place a high emphasis on government, this passage calls attention to you, and your role in the political process. If you want change, do something. What is the responsibility of individuals? What should individuals do to effect change in a positive and non-coercive manner? How might the comics medium be used to initiate and or show this change?

The Dalai Lama's notion of compassion and its relation to humanities global existence is also paramount (King, 2009). The Dalai Lama (Gyatso, 2001, 37) asserts: "I believe that at every level of society- familial, national, and international- the key to a happier and more successful world is the growth of compassion." He stresses how we are all one community and must truly and deeply care for one another. This includes people who hold different political opinions than us. We must hold compassion for those who see the world differently than we do (Gyatso, 2001). Gyatso (Gyatso \& Stril-Rever, 2017, 50) ultimately calls for a "Revolution of Compassion." Compassion for those with different political opinions may take on new significance in our hyper partisan age as well. The discussion of compassion-and its representation in comics, can challenge citizens in new ways. I am writing this as the impeachment of Donald Trump rages in the United States. What would this process look like with compassion? How might the parties treat each other compassionately? The Dalai Lama relates a story of Chinese Buddhist monk who, after being released from a Chinese prison, confided in the Dalai Lama that his biggest fear was that he would lose compassion for the ones who tortured him! What would this level of compassion look like in the real world and comics?

Thich Nhat Hanh (2017) relates a powerful teaching of the Buddha which I think can enhance any notion of critical citizenship. The Buddha urged his followers to never uncritically accept any information-not even the Buddha's own teachings! Rather, the Buddha pressed his followers to 
question everything. There is no one immutable truth (Hanh, 2017). Later Hanh $(2017,39)$ cautions that we should never believe "only we have the truth." King $(2009,60)$ notes that Hanh promoted this view of Buddhism during the Vietnam War because he saw the folly of two immutable ideologies (the United States and USSR) and did not want to offer any rigid truths. Is this not what a good citizen should do? A good citizen should never uncritically accept any piece of information, whether from a parent, church, president, or news source. All must be questioned; even things we take as sacred. This could be a powerful, if not uncomfortable, question: What are things we take as sacred? Are there political dogmas or creeds, on the left or the right, which we need to examine?

Hanh (2017) also talks of signlessness which I think can be related to citizenship - and really challenge our notion of politics and citizenship today. We as humans need to label occurrences with signs, such as birth, death, and the like. While useful, signs can also obscure the interconnectedness of existence. Hanh $(2017,44)$ quotes the Buddha "Where there is a sign, there is always deception." Understanding signlessness helps us fight the urge to "put things into boxes" $(2017,52)$. So let's bring this to our current situation. Republican, democrat, liberal, conservative, CNN, Fox News, may all be boxes, our pathetic attempt to create order. What if citizens could see past these boxes? Perhaps it is far-fetched, and many people make their money by promoting these divisions, but still, what would our politics look like if citizens could see this interconnectedness? And how might this interconnectedness look in comic form?

When can Buddhist political thought be utilized? My guess is that most world history curriculums have some standards related to Buddhism and Eastern religion. I had to teach a small section on Buddhism in both my ancient and modern world history classes when I taught social studies in Virginia. So, there may be ample places to integrate discussion on Buddhism and Eastern philosophy. I also taught Buddhism in my elective philosophy class. The chart below represents a distillation of the Buddhist political ideas examined above that differ from Western conceptions or least offer what I feel are different vantage points. On the left hand side of the chart are some political ideas distilled from the paragraphs above. On the right hand side, students can search comics and graphic novels to see if any of these ideas are present. Of course, many comic creators may not have Buddhist political principles in mind when creating a comic, but that is the beauty of this exercise. The intent here is to equip students with new 
understandings and meanings which they can bring to the comic page to create new interpretations of the page regarding citizenship. I actually performed this exercise. As I was writing this chapter, I was rereading the classic $V$ for Vendetta created by Alan Moore and David Lloyd (If you haven't read it, skip the next paragraph, there are some spoilers.) To be sure, I do not claim that my Buddhist interpretations of $V$ for Vendetta are unproblematic or air tight. The point is not to make a perfect match between Buddhism and a specific work. I think the Buddhist lens can just get students thinking in new ways. The second part of this exercise has students go over the same graphic novel again and look for traditional Western notions of citizenship (The term traditional notions of Western citizenship may be too amorphous. But, this could be the grounds for a great class discussion comparing some differing notions of Buddhist and Western citizenship, such as the role of the self.) Again, students must think critically about how the comics medium, with its use of sequential art, word balloons, facial expressions, nonlinear features, traditional and nontraditional reading patterns, multilinearity, body language, and the like, help to convey important information.

The point is not a simple comparison. I want students to become conversant with new ideas on citizenship but then apply these ideas to their own society. I also want students not only to consider content, but the comics form and how this can enhance the study and application of Buddhism. I think Buddhism can enrich Western notions of citizenship and help cope with the volatile changes of hyperreality. Students can consider these questions: How might Buddhist ideas add to our knowledge of citizenship and political action? What can we learn for our own political struggles in the spectacle? How can we apply Western and Buddhist political ideas in the spectacle to achieve justice? There are a number of logistical challenges which teachers and professors will have to consider. Presumably, high school teachers could not assign an entire graphic novel to read, and college professors probably would not want to if it was not a course specifically dedicated to comics. The teacher may want to pre-read and select some graphic novels or comics for students to choose from, at least in the beginning. The teacher may also need to give some guidance, this will all depend on the nature of the students and the class (Table 2.6).

Analysis of $V$ for Vendetta: To be sure, there are many non-Buddhist readings and things that go against Buddhism in this comic as well (I will get to those shortly). There is even an image of the Buddha in the graphic novel. On page 158 of the Absolute V for Vendetta published in 2009, 
Table 2.6 Buddhism political assignment

Directions: Review the graphic novel excerpts and look for the elements listed below

1. Reconsider the excerpts. Where might traditional western theories of citizenship be present? Be specific and utilize the comics form in your explanation

2. Is there any tension between Buddhist conceptions of citizenship and Western conceptions? Do they work harmoniously or complicate each other? 3. How might the Buddhist notions help us move forward and reconsider our own political situations? What can we learn about politics from the Buddhists? 4. How might these ideas be presented in multimodal fashion? How might art and text enhance these ideas?

\begin{tabular}{|c|c|c|}
\hline Buddhist theme & $\begin{array}{l}\text { How it appears in the } \\
\text { graphic novel (be specific } \\
\text { here) }\end{array}$ & $\begin{array}{l}\text { How is this depicted in the } \\
\text { comics form? }\end{array}$ \\
\hline \multicolumn{3}{|l|}{$\begin{array}{l}\text { Annatta or no-self } \\
\text { doctrine }\end{array}$} \\
\hline \multicolumn{3}{|l|}{$\begin{array}{l}\text { paticca-samuppada/denial } \\
\text { of substance/all related to } \\
\text { all }\end{array}$} \\
\hline \multicolumn{3}{|l|}{$\begin{array}{l}\text { Diminished role of } \\
\text { politics, politics of } \\
\text { salvation }\end{array}$} \\
\hline \multicolumn{3}{|l|}{$\begin{array}{l}\text { Compassion for everyone, } \\
\text { even political opponents }\end{array}$} \\
\hline \multicolumn{3}{|l|}{$\begin{array}{l}\text { Change from within (as } \\
\text { opposed to relying on } \\
\text { politicians) }\end{array}$} \\
\hline \multicolumn{3}{|l|}{$\begin{array}{l}\text { Critical examination of } \\
\text { everything/question } \\
\text { sacred ideas }\end{array}$} \\
\hline \multicolumn{3}{|l|}{ Signlessness } \\
\hline $\begin{array}{l}\text { Concern for } \\
\text { ecology/environment }\end{array}$ & & \\
\hline
\end{tabular}

$\mathrm{V}$ is standing in front of a Buddhist statue when addressing the public. One prominent Buddhist element in the work may be the idea of the "noself." On page $357 \mathrm{~V}$ tells the crowd "I would introduce myself, but truth to tell, I do not have a name." The art work helps to convey this message. We see V's definitive mask, locked in smile, we see his silhouette perched on a roof speaking to the multitude, and see a raucous crowd. We do not know who $\mathrm{V}$ really is. There is some musing in the graphic novel that $\mathrm{V}$ 
might be Evey's father (which Alan Moore, in a postscript, denies). At one point, $\mathrm{V}$ impersonates a prison warden to torture Evey. This scene is brutal, as we see Evey almost completely break. One page $37, \mathrm{~V}$ is wearing a Vaudeville mask, which he wears as he tortures Lewis Prothero. And V is obviously likened to Guy Fawkes. V's trademark mask has become his face, his symbol, which again, is driven home by the art. In the end, Evey does not unmask $\mathrm{V}$ after he dies, and perpetuates this no-self as she sends him off to his "Viking funeral" (Moore \& Lloyd, 2009, 360). Of course, V's use of violence contradicts complicates matters. Another difference is V's elevation of politics, indeed, he does not disengage from politics to seek individual salvation, he uses politics and political (terrorist actions) to achieve political goals.

For the above activity, I selected nuggets of Buddhist thought. A more active variation of this activity has students distill their own political insights from Buddhism. The Dalai Lama's writings are voluminous. He speaks eloquently and passionately about environment-an important concern for Buddhism. This made me think of Poison Ivy. Poison Ivy from Batman's rouge gallery is an eco-terrorist (DC homepage, 2019). While I do not think the Dalai Lama would agree with Poison Ivy's methods, they both show a great political concern for the environment. Students could mine the Dalai Lama's interviews and statements and writings, distill their own political themes and find comics and graphic novels where these themes might be present. Again, the teacher will need to determine the level of guidance they will give to their students regarding how students will go about using specific comics.

The next activity has students add some Buddhist elements to a story. For instance, as noted earlier, there is one image of a Buddhist statue in $V$ for Vendetta. The inclusion of this image raises some interesting interpretation questions. What does it mean? How does it impact the story? Teachers can use the $V$ for Vendetta image of Buddha as an example of a small Buddhist element in a story which impacts the meaning of the story. Students can review a comic and propose the addition of diegetic elements or non-diegetic elements, and these elements can be in the form of images or words. Similarly, students can speculate about how changing aspects of the form (e.g., speech bubbles, panel size) may also add Buddhist elements to the story. Students could also be given an excerpt of some of Groensteen's (2007) writing pertaining to braiding and motifs. Could students create a Buddhist motif? Teachers will have to decide if 
they will preselect comics or let students choose, or some combination of both.

\section{Adding Buddhism Assignment}

Directions: Read the excerpt you are given. Drawing on your knowledge of Buddhism, answer the questions below:

1. Can you add any Buddhist elements, such as quotes or images, which can enhance the story or create new layers of meaning in the story?

2. Can you create any Buddhist motifs to weave through the story which can add new layers of meaning?

\section{REFERENCES}

Alaniz, J. (2016). Standing orders: Oracle, disability and retconning. In Z. Wahlem, C. Foss, \& C. Gray (Eds.), Disability in comic books and graphic novels (pp. 59-79). New York: Palgrave Macmillan.

Banks, J. A., McGee-Banks, C. A., \& Clegg, A. A. (1999). Teaching strategies for the social studies: Decision-making and citizen action (5th ed.). New York: Longman.

Barclay, E. (2019, October 11). Thich Nhat Hanh's final mindfulness lesson: How to die peacefully. Vox. Retrieved from https://www.vox.com/2019/3/11/ $18196457 /$ thich-nhat-hanh-health-mindfulness-plum-village.

Cabero, E. (2019). Beyond linearity: Holistic multidirectional, multilinear and translinear reading in comics. The Comics Grid: Journal of Comics Scholarship, $9(1): 5,1-21$.

Carter, J. B. (2011). Graphic novels, web comics, and creator blogs: Examining product and process. Theory into Practice, 50, 190-197. https://doi.org/10. 1080/00405841.2011.584029.

Chapin, J. (2015). A practice guide to middle and secondary social studies (4th ed.). New York: Pearson.

Cohen, J., Pickeral, T., \& Levine, P. (2010). The foundation for democracy: Promoting social, emotional, ethical, cognitive skills and dispositions in K-12 schools. Interamerican Journal of Education for Democracy, 3(1), 74-94.

Cohn, N. (2013). The visual language of comics. New York, NY: Bloomsbury. 
Cohn, N. (2018). In defense of "grammar" in the visual language of comics. Journal of Pragmatics, 127, 1-19. https://doi.org/10.1016/j.pragma.2018. 01.002 .

Cook, M., \& Frey, R. (2017). Using superheroes to visually and critically analyze comics, stereotypes, and society. SANE Journal: Sequential Art Narrative in Education, 2(2), Article 1. Available at http://digitalcommons.unl.edu/sane/ $\operatorname{vol} 2 /$ iss $2 / 1$.

Dayton, J. (2012). Education law: Principles, policies, and practices. Lexington, KY: Wisdom Buildings Press.

Dong, L. (2013). Beyond borders: Teaching global awareness through the graphic novel. In C. K. Syma \& R. Weiner (Eds.), Graphic novels and comics in the classroom (pp. 220-232). Jefferson, NC: McFarland.

Duncan, R., Smith, M., \& Levitz, P. (2015). The power of comics: History, form and culture (2nd ed.). New York: Bloomsbury.

Duncombe, S. (2019). Dream or nightmare: Reimagining politics in an age of fantasy (2nd ed.). New York: OR Books.

Eckel, M. D. (2001). Buddhism: Course guide book. Chantilly, VA: The Great Courses.

Eckel, M. D. (2010). Buddhism. New York: Rosen Publishing.

Eisner, W. (2002). Comics and sequential art: Principles and practices from the legendary cartoonist. New York: W. W. Norton.

Garland-Thomson, R. (2016). Foreward. In C. Foss, J. W. Gray, \& Z. Whalen (Eds.), Disability in comics and graphic novels (pp. $\mathrm{x}$-xiii). New York: Palgrave Macmillan.

Getz, T., \& Clarke, L. (2011). Abina and the important men: A graphic history. New York: Oxford University Press.

Groensteen, T. (2007). The system of comics (B. Beaty \& N. Nguyen, Trans.). Jackson, MS: University of Mississippi Press.

Groensteen, T. (2013). Comics and narration. Jackson, MS: University of Mississippi Press.

Gyatso, T. (2001). The compassionate life. Boston, MA: Wisdom Publications.

Gyatso, T., \& Stril-Rever, S. (2017). A call for revolution: A vision of the future. New York: Harper Collins.

Hanh, T. N. (2017). The art of living: Peace and freedom in the here and now. New York: Harper One.

Halsall, A. (2018). What is the use of a book...without pictures or conversations?; Incorporating the graphic novel into the university curriculum. In A. Burger (Ed.), Teaching graphic novels in the English classroom: Pedagogical possibilities of multimodal literacy engagement (pp. 87-102). New York: Palgrave Macmillan.

Hoeness-Krupsaw, S. (2018). Teaching March in the borderlands between social justice and pop culture. In A. Burger (Ed.), Teaching graphic novels in the 
English classroom: Pedagogical possibilities of multimodal literacy engagement (pp. 135-148). New York: Palgrave Macmillan.

Hutchinson, R. (2009). Teaching manga: Considerations and class exercises. In S. Tabachnick (Ed.), Teaching the graphic novel (pp. 262-270). New York: Modern Language Publishing.

Jacobson, N. P. (1983). Buddhism \& the contemporary world: Change and selfcorrection. Carbondale, IL: Southern Illinois University Press.

Kessler, G. E. (2001). Voices of wisdom: A multicultural philosophy reader (4th ed.). Belmont, CA: Cengage.

Kincheloe, J. (2001). Getting beyond the facts: Teaching social studies/social sciences in the twenty-first century (2nd ed.). New York: Peter Lang.

King, S. (2009). Socially engaged Buddhism. Honolulu, HA: University of Hawai'i Press.

Larson, B. (2017). Instructional strategies for middle and high school social studies (2nd ed.). New York: Routledge.

McCloud, S. (1994). Understanding comics. New York: Harper Perennial.

McLaughlin, J. (2012). Philosophy: "The triumph of the human spirit" in XMen. In M. Smith \& R. Duncan (Eds.), Critical approaches to comics: Theories and methods (pp. 103-115). New York: Routledge.

Meyer, C. K., \& Jimenez, L. M. (2017). Using every word and image: Framing graphic novel instruction in the expanded four resources model. Journal of Adolescent \& Adult Literacy, 61(2), 153-161. https://doi.org/10.1002/ jaal.666.

Moore, A., \& Lloyd, D. (2009). V for Vendetta: Absolute edition. New York: DC Comics.

Moore, M. J. (2015). Political theory in canonical Buddhism. Philosophy East \& West, 65(1), 36-64.

Moore, M. J. (2016). Buddhism and political theory. New York: Oxford University Press.

National Council for the Social Studies. (2020). National curriculum standards. Retrieved from https://www.socialstudies.org/standards/strands.

Novak, R. J. (2014). Teaching graphic novels in the classroom: Building literacy and comprehension. Waco, TX: Prufrock Press.

Parker, W. (1996). Curriculum and democracy. In R. Soder (Ed.), Democracy education, and the schools (pp. 182-210). San Francisco: Jossey-Bass.

Poison Ivy. 2019. DC homepage. Retrieved from https://www.dccomics.com/ characters/poison-ivy.

Potts, C. (2013). The DC comics guide to creating comics: Inside the art of visual storytelling. New York: Crown Publishing.

Ricca, B. J. (2012). History: Discovering the story of Jerry Siegel and Joe Shuster. In M. Smith \& R. Duncan (Eds.), Critical approaches to comics: Theories and methods (pp. 189-199). New York: Routledge. 
Ross, W. E., Mathison, S., \& Vinson, K. D. (2014). Social studies curriculum teaching in the era of standardization. In W. Ross (Ed.), The social studies curriculum: Purposes, problems, and possibilities (4th ed., pp. 25-50). Albany, NY: SUNY Press.

Saraceni, M. (2016). Relatedness: Aspects of textual connectivity in comics. In N. Cohn (Ed.), The visual narrative reader (pp. 115-127). New York: Bloomsbury.

Shealy, C. N. (2014). Our belief in belief. In C. N. Shealy (Ed.), Making sense of beliefs and values: Theory research and practice (pp. 3-18). New York: Springer.

Torney-Purta, J., \& Vermeer Lopez, S. (2006). Developing citizenship competencies from kindergarten through grade 12: A background paper for policymakers and educators. Denver, CO: Education Commission of the States.

Vandiver, E. (2000a). Classical mythology: Part 1. Chantilly, VA: The Teaching Company.

Vandiver, E. (2000b). Classical mythology: Part 2. Chantilly, VA: The Teaching Company.

Westheimer, J., \& Kahne, J. (2004). What kind of citizen? The politics of educating for democracy. American Education Research Journal, 41(2), 237-269.

Whalen, Z., Foss, C. W., \& Gray, C. (2016). Introduction: From feats of clay to narrative prose/thesis. In C. Foss, J. W. Gray, \& Z. Whalen (Eds.), Disability in comics and graphic novels (pp. $\mathrm{x}$-xiii). New York: Palgrave Macmillan.

Wolk, D. (2007). Reading comics: How graphic novels work and what they mean. New York: Da Capo.

Woolfork, A. (2016). Educational psychology (14th ed.). New York: Pearson.

Zevin, J. (2000). Social studies for the twenty-first century: Methods and materials for teaching in middle and secondary schools (2nd ed.). Mahwah, NJ: Lawrence Erlbaum Associates. 